\title{
Article \\ Microstructure and Mechanical Properties of CoWB Based Composites Produced by Crystallization of Ni-Co-Zr-Ta-W-B Bulk Metallic Glass
}

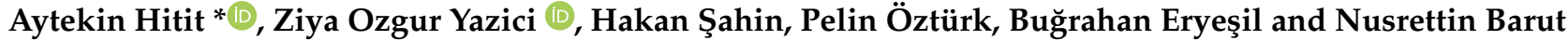

check for updates

Citation: Hitit, A.; Yazici, Z.O.; Şahin, H.; Öztürk, P.; Eryeşil, B.; Barut, N. Microstructure and Mechanical Properties of CoWB Based Composites Produced by Crystallization of Ni-Co-Zr-Ta-W-B Bulk Metallic Glass. Metals 2022, 12, 251. https://doi.org/10.3390/ met12020251

Academic Editor: Jordi Sort

Received: 6 January 2022

Accepted: 25 January 2022

Published: 28 January 2022

Publisher's Note: MDPI stays neutral with regard to jurisdictional claims in published maps and institutional affiliations.

Copyright: (C) 2022 by the authors. Licensee MDPI, Basel, Switzerland. This article is an open access article distributed under the terms and conditions of the Creative Commons Attribution (CC BY) license (https:// creativecommons.org/licenses/by/ $4.0 /)$.
Department of Materials Science and Engineering, Afyon Kocatepe University, Afyonkarahisar 03200, Turkey; zyazici@aku.edu.tr (Z.O.Y.); hakansahin@aku.edu.tr (H.Ş.); pelinsuozturk@gmail.com (P.Ö.); bugrahaneryesil@gmail.com (B.E.); nusrettinbarut@hotmail.com (N.B.)

* Correspondence: hitit@aku.edu.tr; Tel.: +90-272-218-2354

\begin{abstract}
CoWB based composites were produced by annealing $\mathrm{Ni}_{33.6} \mathrm{Co}_{23.2} \mathrm{Zr}_{0.5} \mathrm{Ta}_{4} \mathrm{~W}_{23.7} \mathrm{~B}_{15}$ bulk metallic glass above the crystallization temperature. The effect of annealing on the microstructure of the composites was investigated by X-ray diffraction (XRD) and scanning electron microscopy (SEM). Microhardness $(\mathrm{Hv})$ and indentation fracture toughness $\left(\mathrm{K}_{\mathrm{C}}\right)$ of the composites were also measured. Microstructural examinations revealed that the first precipitated phase as a result of annealing is a nickel solid solution. As the annealing time is increased, CoWB and the nickel solid solution begins to precipitate. If the annealing time is increased further, the CoWB remains stable, while the nickel solid solution transforms into $\mathrm{Ni}_{3} \mathrm{Ta}$. The microhardness of the as-cast alloy was determined to be $1190 \mathrm{HV}$. As a result of annealing, composites with a microhardness of around $1400 \mathrm{HV}$ were obtained due to the precipitation of CoWB. $K_{C}$ of the composite with the maximum hardness was determined to be $\sim 3 \mathrm{MPa} \cdot \mathrm{m}^{1 / 2}$. The effect of microstructure on the mechanical properties of the composites is discussed.
\end{abstract}

Keywords: bulk metallic glass; crystallization; composite; mechanical properties; ternary borides; CoWB

\section{Introduction}

Boride-based composites have attractive properties such as high hardness, high strength, high chemical stability, and excellent wear resistance. In addition, boride-based composites have higher high-temperature oxidation resistance compared to carbide-based composites [1-3]. Many boride based composites reinforced with $\mathrm{TiB}_{2}$ [4-6], $\mathrm{TiB}$ [7], $\mathrm{ZrB}_{2}$ [5], $\mathrm{Mo}_{2} \mathrm{NiB}_{2}$ [8-10], $\mathrm{W}_{2} \mathrm{NiB}_{2}$ [11,12], $\mathrm{Mo}_{2} \mathrm{FeB}_{2}$ [9,13-18], FeWB [19,20], CoWB [21,22], and Mo$\mathrm{CoB}[23]$ have been developed. These composites are produced by sintering.

It has been shown that boride-based composites can also be produced by crystallization of bulk metallic glasses with high boron content [24-27]. The main advantage of producing boride based composites by crystallization of bulk metallic glasses is that composite material with the desired geometry can be obtained by casting and subsequent heat treatment. Reinforcing phases of these composites are $\mathrm{Fe}_{3} \mathrm{~B}, \mathrm{Fe}_{2} \mathrm{~B},(\mathrm{Co}, \mathrm{Fe})_{2} \mathrm{~B}, \mathrm{Fe}_{23} \mathrm{~B}_{6}$, $(\mathrm{Fe}, \mathrm{Ni}, \mathrm{Mo})_{23} \mathrm{~B}_{6},(\mathrm{Fe}, \mathrm{Cr})_{23}(\mathrm{C}, \mathrm{B})_{6},(\mathrm{Co}, \mathrm{Fe})_{21} \mathrm{Ta}_{2} \mathrm{~B}_{6}, \mathrm{MoB}$, and CoWB. The microhardness of these composites varies between 1400 and $1800 \mathrm{HV}$. Among these composites, only the composite developed by devitrification of the bulk metallic glass $\mathrm{Ni}_{36.3} \mathrm{Co}_{25} \mathrm{~W}_{23.7} \mathrm{~B}_{15}$ contains a ductile phase [27]. This composite consists of a nickel solid solution with a face centered cubic (FCC) structure and CoWB phase. Since the reinforcement phase of the composite, CoWB, is a phase with extremely high hardness, which is $4000 \mathrm{HV}[1,27]$, this alloy system has a very high potential to be used as a precursor in the production of composites with high hardness and high fracture toughness. However, the glass forming ability (GFA) of the alloy is quite low, and its critical casting thickness is only $0.5 \mathrm{~mm}$, which limits its usage 
potential. It has been recently shown that the GFA of Ni-Co-W-B bulk metallic glasses can be improved by tantalum additions [28]. Since tantalum-modified Ni-Co-W-B bulk metallic glasses have higher critical casting thickness, CoWB based composite materials to be produced by crystallization of these alloys will find a wider range of usage. Therefore, the potential of these alloys to be used as a precursor in the production of CoWB based composite materials should be revealed.

In this study, composites are produced by the devitrification of $\mathrm{Ni}_{33.6} \mathrm{Co}_{23.2} \mathrm{Zr}_{0.5} \mathrm{Ta}_{4} \mathrm{~W}_{23.7} \mathrm{~B}_{15}$ bulk metallic glass, whose critical casting thickness is $1.5 \mathrm{~mm}$. The effects of annealing on the microstructure and mechanical properties of the composites are investigated.

\section{Materials and Methods}

The master alloy $\mathrm{Ni}_{33.6} \mathrm{Co}_{23.2} \mathrm{Zr}_{0.5} \mathrm{Ta}_{4} \mathrm{~W}_{23.7} \mathrm{~B}_{15}$ (in at.\%) was prepared by arc melting of the high purity metals $\mathrm{Ni}(99.9 \mathrm{wt} . \%), \mathrm{Co}(99.8 \mathrm{wt} . \%), \mathrm{Zr}(99.2 \mathrm{wt} . \%)$, Ta (99.9 wt.\%), and W (99.9 wt.\%), and pure crystalline B (98 wt.\%) (Alfa Aesar, Ward Hill, MA, USA) in a Ti-Zr gettered ultra-high purity argon atmosphere. The alloy ingots were melted at least three times to ensure homogeneity. Alloy samples of $0.5 \mathrm{~mm}$ thickness were produced by the suction casting method in an arc furnace. The glass transition $\left(T_{g}\right)$, crystallization $\left(T_{x}\right)$, and liquidus $\left(T_{l}\right)$ temperatures of the alloy were measured by differential scanning calorimetry (DSC) (NETZSCH Group, Selb, Germany). A heating rate of $20 \mathrm{~K} / \mathrm{min}$ was used to measure $T_{g}$ and $T_{x}$. After melting the sample completely by reaching a temperature of $1840 \mathrm{~K}$, a cooling rate of $20 \mathrm{~K} / \mathrm{min}$ was used to measure $T_{l}$. To produce composite samples, the fully amorphous samples were annealed at temperatures above the crystallization temperature. $1025 \mathrm{~K}$ was selected as the annealing temperature and the samples were heat treated for 10, $25,50,75,100,125$, and $150 \mathrm{~min}$. The structures of the as-cast and composite samples were examined by $\mathrm{X}$-ray diffraction (Bruker AXS, Karlsruhe, Germany) with $\mathrm{Cu}-\mathrm{K}_{\alpha}$ radiation. XRD data of the composite samples were refined with the Rietveld method using the Microstructural Analysis Using Diffraction (MAUD) software (Version 2.94, University of Trento, Trento, Italy). Microstructures of the composite samples were examined with SEM (FEI Company, Hillsboro, OR, USA). For this examination, the backscattered electron (BSE) imaging mode was used. The Vickers hardness test (Shimadzu Corporation, Kyoto, Japan) was used to determine the microhardness of the as-cast and annealed samples. For microhardness tests, a load of $2.94 \mathrm{~N}$ was applied for $15 \mathrm{~s}$. For each sample, 10 microhardness measurements were taken randomly from different regions on the sample surface. The average of these measurements was taken as the microhardness value of that sample. To determine the Kc of the composite samples, loads up to $19.6 \mathrm{~N}$ were applied. In SEM, the secondary electron (SE) imaging mode was used to acquire images of the indents obtained from microhardness tests.

\section{Results}

\subsection{Thermal Behaviour}

A DSC scan of the amorphous alloy $\mathrm{Ni}_{33.6} \mathrm{Co}_{23.2} \mathrm{Zr}_{0.5} \mathrm{Ta}_{4} \mathrm{~W}_{23.7} \mathrm{~B}_{15}$ alloy used as the precursor to produce composites reveals that the $T_{g}$ of the alloy is $901 \mathrm{~K}$ (Figure 1). Two crystallization peaks, $T_{x 1}$ and $T_{x 2}$, are observed, and their values are measured as 981 and $1110 \mathrm{~K}$, respectively. The presence of two crystallization peaks indicates that during devitrification, two crystallization events, involving the precipitation of multiple crystalline phases, occur. Also, the $T_{l}$ of the alloy is measured during cooling and determined to be $1583 \mathrm{~K}$.

\subsection{XRD Results}

Figure 2 shows the XRD patterns of the composites produced by annealing the fully amorphous samples at $1025 \mathrm{~K}$ for 10 to $150 \mathrm{~min}$. After annealing the fully amorphous sample for $10 \mathrm{~min}$, the nickel solid solution (Ni-phase), which has an FCC structure, precipitates. Since cobalt is completely soluble with nickel and the solubility of tungsten and tantalum in nickel are $\sim 12.5$ and $\sim 11$ at. $\%$, respectively [29], the nickel solid solution 
contains significant amounts of cobalt, tungsten, and tantalum. In addition, the composite sample contains a considerable amount of amorphous phase.
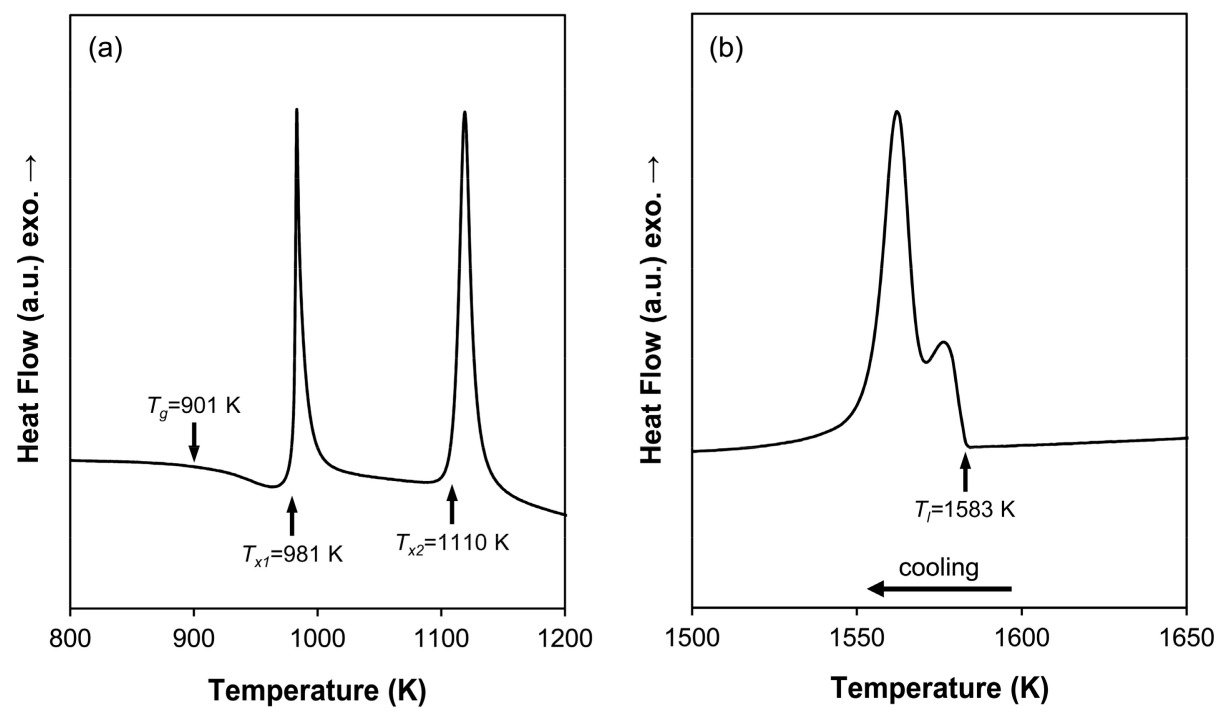

Figure 1. DSC scan of $\mathrm{Ni}_{33.6} \mathrm{Co}_{23.2} \mathrm{Zr}_{0.5} \mathrm{Ta}_{4} \mathrm{~W}_{23.7} \mathrm{~B}_{15}$ alloy. (a) Glass transition and crystallization behavior, (b) Melting behavior.



Figure 2. XRD patterns of the samples annealed at $1025 \mathrm{~K}$.

After increasing the annealing time to $50 \mathrm{~min}$, a small amount of CoWB precipitates besides the Ni-phase. It should be noted that there is still some amount of amorphous phase in the composite. With 100 min of annealing, the CoWB has a higher volume fraction. Also, there is some amount of Ni-phase in the composite sample. In addition to these two phases, another phase, $\mathrm{Ni}_{3} \mathrm{Ta}$, precipitates in the microstructure. The volume fraction of CoWB increases slightly after annealing for $150 \mathrm{~min}$. However, there is a considerable 
increase in the volume fraction $\mathrm{Ni}_{3} \mathrm{Ta}$ while the volume fraction of the Ni-phase decreases. The decrease in the intensity of (200) the peak of Ni-phase, which is located at $2 \theta=50.18^{\circ}$, indicates that the volume fraction of the Ni-phase is quite small. This result reveals that the $\mathrm{Ni}$-phase transforms into $\mathrm{Ni}_{3} \mathrm{Ta}$. Since the Ni-phase is a solid solution containing $\mathrm{Ni}, \mathrm{Co}$, $\mathrm{W}$, and $\mathrm{Ta}, \mathrm{Ni}_{3} \mathrm{Ta}$ should also contain $\mathrm{Co}$ and $\mathrm{W}$ in addition to $\mathrm{Ni}$ and Ta. Therefore, $\mathrm{Ni}_{3} \mathrm{Ta}$ forms as $(\mathrm{Ni}, \mathrm{Co})_{3}(\mathrm{Ta}, \mathrm{W})$. The lattice constants of the phases precipitating in the composites were determined by Rietveld analysis (Table 1).

Table 1. The lattice constants of the observed phases.

\begin{tabular}{cccc}
\hline Phase & $\begin{array}{c}\mathbf{a} \\
\mathbf{( n m )}\end{array}$ & $\begin{array}{c}\mathbf{b} \\
\mathbf{( n m})\end{array}$ & $\begin{array}{c}\mathbf{c} \\
(\mathbf{n m})\end{array}$ \\
\hline $\mathrm{Ni}(\mathrm{Fm} 3 \mathrm{~m})$ & $0.3623 \pm 0.0001$ & - & - \\
$\mathrm{CoWB}(\mathrm{Pnma})$ & $0.5745 \pm 0.0001$ & $0.3244 \pm 0.0001$ & $0.6663 \pm 0.0001$ \\
$\mathrm{Ni}_{3} \mathrm{Ta}(\mathrm{Pmmn})$ & $0.5073 \pm 0.0004$ & $0.4183 \pm 0.0004$ & $0.4507 \pm 0.0004$ \\
\hline
\end{tabular}

Also, the Rietveld refinement of the XRD data of the composites produced by annealing the amorphous samples at $1025 \mathrm{~K}$ for 100 and $150 \mathrm{~min}$ was carried out to determine the volume fractions of the phases (Figure 3).
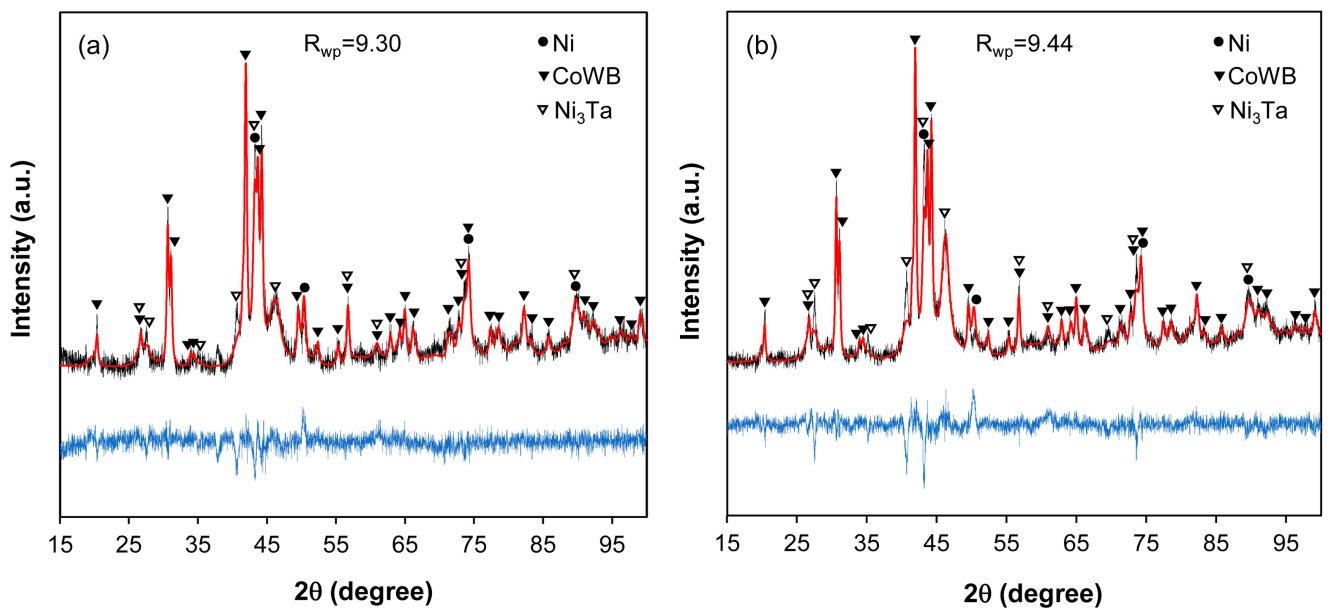

Figure 3. The Rietveld refinement of the XRD data of the composites produced by annealing the amorphous alloy at $1025 \mathrm{~K}$ for (a) $100 \mathrm{~min}$, (b) $150 \mathrm{~min}$. Observed data is indicated by black color. Calculated and difference data are represented by red and blue colors, respectively.

The results revealed that the volume fraction CoWB is $\sim 0.4$ in the composites obtained after annealing the amorphous alloy for 100 and $150 \mathrm{~min}$ (Table 2). After annealing for $100 \mathrm{~min}$, the volume fractions of $\mathrm{Ni}$-phase and $\mathrm{Ni}_{3} \mathrm{Ta}$ are determined to be $\sim 0.2$ and 0.4 , respectively. As the annealing temperature is increased to $150 \mathrm{~min}$, the volume fraction of Ni-phase decreases and becomes 0.1 , whereas the volume fraction of $\mathrm{Ni}_{3} \mathrm{Ta}$ increases to $\sim 0.5$.

Table 2. The volume fractions of the phases precipitated in the composites.

\begin{tabular}{cccc}
\hline $\begin{array}{c}\text { Annealing Time } \\
\text { (min) }\end{array}$ & Ni-Phase & CoWB & $\mathbf{N i}_{3} \mathbf{T a}$ \\
\hline 100 & 0.18 & 0.42 & 0.40 \\
150 & 0.12 & 0.38 & 0.50 \\
\hline
\end{tabular}

Since the Ni-phase transforms into $(\mathrm{Ni}, \mathrm{Co})_{3}(\mathrm{Ta}, \mathrm{W})$, both phases must have the same composition. It is possible to estimate the $\mathrm{Ni}, \mathrm{Co}, \mathrm{W}$, and Ta contents of the Ni-phase. 
Because boron is not soluble in $\mathrm{Ni}$ [29] and there exits only one phase containing boron, all of the boron atoms are expected to be in CoWB after completion of the crystallization. Therefore, CoWB contains 45 at.\% of the atoms, which are 15 at. \% B, 15 at. \% Co, and 15 at. $\% \mathrm{~W}$. The remaining 55 at.\% atoms, 33.6 at.\% Ni, 8.2 at.\% Co, 0.5 at.\% Zr, 8.7 at.\% W, and 4 at.\% Ta, must be in the Ni-phase. As a result, the mole fractions of the components, $X_{N i}, X_{C o}, X_{Z r}, X_{W}$, and $X_{T a}$, are determined to be, $0.61,0.15,0.01,0.16$, and 0.07 , respectively. These results show that total nickel and cobalt content and total tungsten and tantalum content of the Ni-phase are 76 at. \% and 24 at.\%, respectively, which perfectly satisfies the stoichiometry of $(\mathrm{Ni}, \mathrm{Co})_{3}(\mathrm{Ta}, \mathrm{W})$. It should be noted that zirconium is assumed to be in the tantalum and/or tungsten positions.

The validity of this estimation can be checked by calculating the lattice parameter of the Ni-phase by using the mole fractions and average radii of the components and comparing it to the experimentally measured value. It is known that for an FCC unit cell, the relationship between the lattice constant, $a$, and the atomic radius, $r$, is:

$$
a=\frac{4 r}{\sqrt{2}}
$$

The average atomic radius of the elements in $\mathrm{Ni}$-phase is:

$$
\bar{r}=\sum X_{i} r_{i}
$$

where atomic radii of the elements, $r_{N i}, r_{C o}, r_{Z r}, r_{W}$ and $r_{T a}$, are $0.1246,0.1251,0.1603$, 0.1367 , and $0.143 \mathrm{~nm}$, respectively [30]. The average radius is determined to be $0.1283 \mathrm{~nm}$. By using this value, the lattice constant of the Ni-phase is calculated as $0.3628 \mathrm{~nm}$, which is very close to the measured value of $0.3623 \mathrm{~nm}$. These results clearly show that mole fractions of the elements forming the Ni-phase were estimated correctly.

\subsection{SEM Analyses}

SEM images acquired from the composite samples are shown in Figure 4 . The 50 min annealed sample contains the Ni-phase and the CoWB.
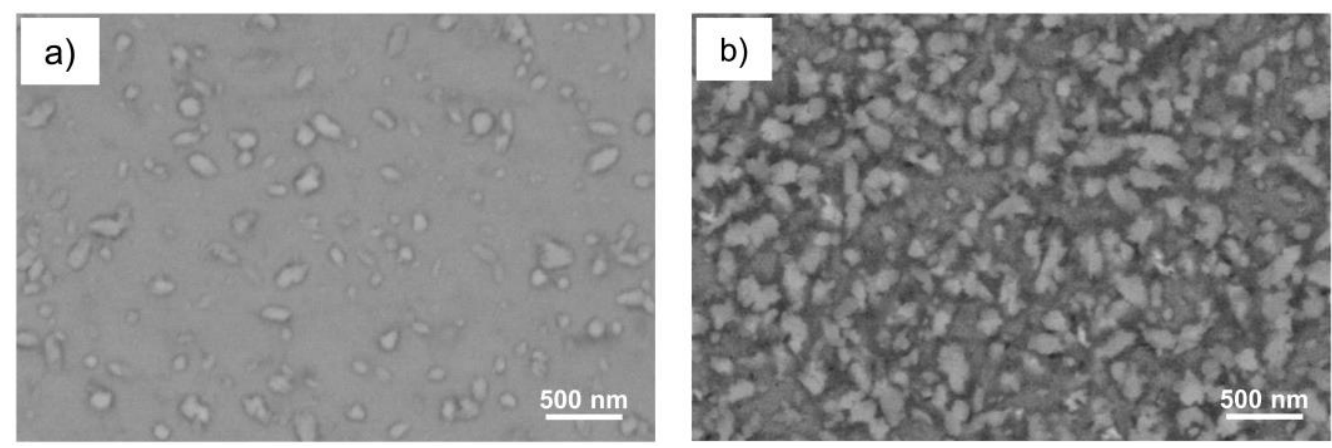

Figure 4. SEM images of the samples annealed at $1025 \mathrm{~K}$ for (a) $50 \mathrm{~min}$, (b) $100 \mathrm{~min}$.

It was found that the volume fraction of CoWB is 0.12 . It was also determined that the average particle size of CoWB precipitates is $74 \mathrm{~nm}$. The $100 \mathrm{~min}$ annealed sample contains the Ni-phase, $\mathrm{CoWB}$, and $\mathrm{Ni}_{3} \mathrm{Ta}$. The compositions of the Ni-phase and $\mathrm{Ni}_{3} \mathrm{Ta}$ are the same, so they have the same average atomic number per unit volume (Table 3). For this reason, it is not possible to distinguish these two phases in the SEM image obtained with the BSE mode. Only the CoWB phase, which has the highest average atomic number per unit volume, can be distinguished from the others. The volume fraction of CoWB was determined to be 0.35 , which is consistent with the result obtained from the Rietveld refinement. In addition, it was determined that the average grain size of the CoWB was $86 \mathrm{~nm}$. 
Table 3. Average atomic number per unit volume of the phases precipitate in the composites.

\begin{tabular}{cc}
\hline Phase & $\begin{array}{c}\text { Average Atomic Number } \\
\left(\mathbf{Z} / \AA^{\mathbf{3}} \mathbf{)}\right.\end{array}$ \\
\hline $\mathrm{Ni}$ & 2.901 \\
$\mathrm{Ni}_{3} \mathrm{Ta}$ & 2.893 \\
$\mathrm{CoWB}$ & 3.415 \\
\hline
\end{tabular}

\subsection{Microhardness}

The as-cast sample has a microhardness of $1190 \mathrm{HV}$. The microhardness values of the composites are given in Figure 5. After $10 \mathrm{~min}$. of annealing, the microhardness of the composite is measured as $1352 \mathrm{HV}$. As the annealing time increased, the microhardness value increased and the highest hardness value of $1410 \mathrm{HV}$ is obtained as a result of $75 \mathrm{~min}$. of heat treatment. A hardness value of $1403 \mathrm{HV}$ is obtained after $100 \mathrm{~min}$ of annealing. Microhardness of the composite decreases as a result of a further increase in annealing time.

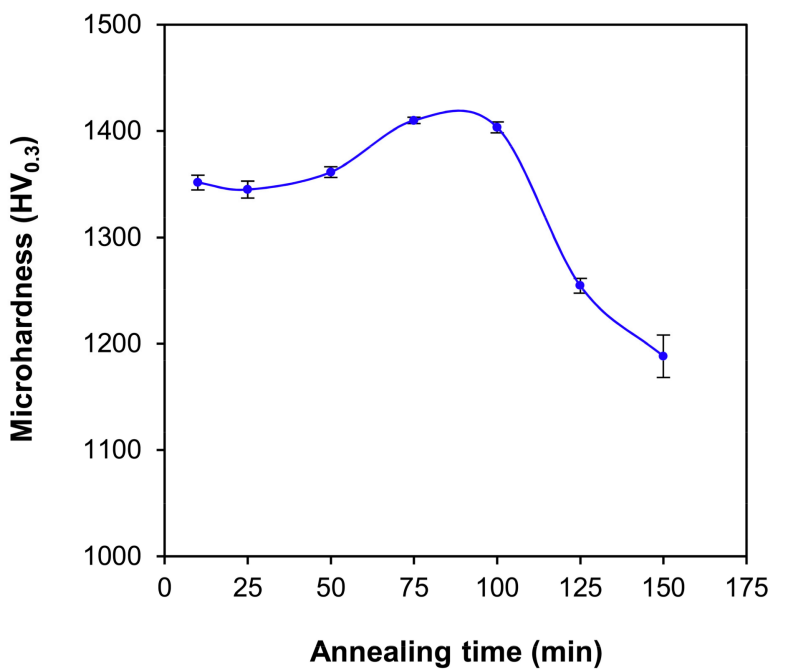

Figure 5. Microhardness of the samples annealed at $1025 \mathrm{~K}$.

\subsection{Indentation Fracture Toughness}

The $\mathrm{K}_{\mathrm{C}}$ of the composite sample with the highest microhardness, which is obtained by annealing the amorphous alloy at $1025 \mathrm{~K}$ for $100 \mathrm{~min}$, was determined. An example of an indent used for the calculation is given in Figure 6. The calculations showed that $\mathrm{K}_{\mathrm{C}}$ of the composite ranges between 2.9 and 3.7 MPa.m ${ }^{1 / 2}$ (Table 4 ). The $\mathrm{K}_{\mathrm{C}}$ values given in Table 4 are the arithmetic mean of the calculations made using the measurements obtained from three different indents.

Table 4. Indentation fracture toughness of the composite with the highest microhardness.

\begin{tabular}{|c|c|c|}
\hline Equation & $\begin{array}{c}\mathrm{K}_{\mathrm{C}} \\
\left(\mathrm{MPa} \cdot \mathrm{m}^{1 / 2}\right)\end{array}$ & Ref. \\
\hline$K_{C}=0.079\left(\frac{P}{a^{1.5}}\right) \log \left(\frac{4.5 a}{c}\right)$ & 3.7 & Evans \& Wilshaw [31] \\
\hline$K_{C}=0.45\left(\frac{H_{v} a^{0.5}}{\Phi}\right)\left(\frac{c}{a}\right)^{-1.5}$ & 2.9 & Evans \& Charles [32] \\
\hline
\end{tabular}




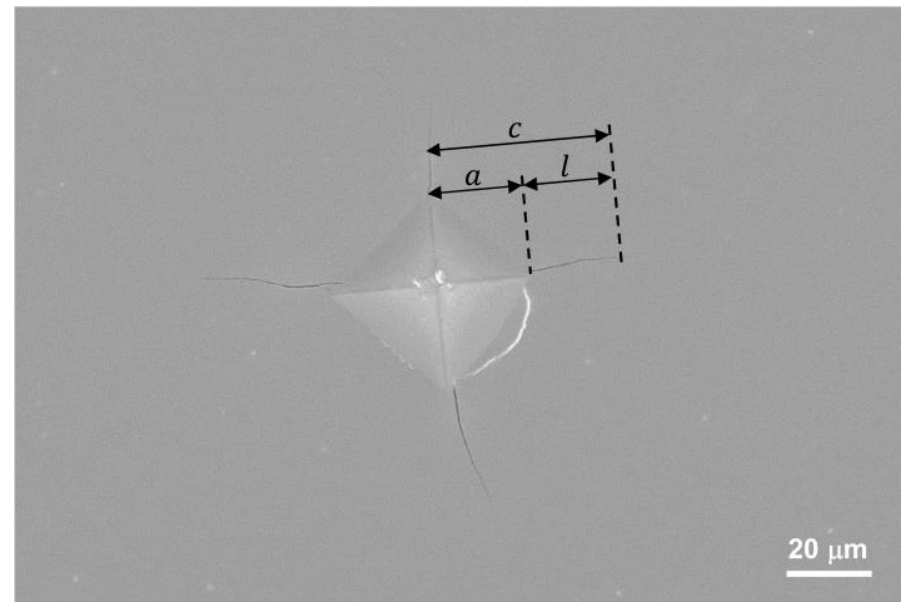

Figure 6. SEM image of an indent obtained from the composite with the highest microhardness by applying a load of $19.6 \mathrm{~N}$.

\section{Discussion}

During the heat treatment, the first precipitating phase is the Ni-phase, a nickel solid solution containing nickel, cobalt, tungsten, and tantalum. Although the solubility limits of tungsten and tantalum in nickel are $\sim 12.5$ and $~ 11$ at.\%, respectively, the total tungsten and tantalum content of the Ni-phase is about 24 at.\%. Such a high solubility of tungsten in nickel has also been observed in Ni-W alloys prepared by mechanical alloying [33] and electrodeposition [34,35].

The microhardness of Ni-25 at.\% W solid solution with a grain size of $12 \mathrm{~nm}$ is about $1450 \mathrm{HV}$ [34]. Because it is the majority phase in the composites obtained as a result of annealing for less than $50 \mathrm{~min}$, the microhardness of the composites is about $1350 \mathrm{HV}$. When the annealing time is increased to $50 \mathrm{~min}$, the precipitation of CoWB begins, so the microhardness of the composite increases slightly. The volume fraction of CoWB continues to increase with the increasing annealing time. Therefore, the microhardness of the composite also increases and reaches its maximum value, $1410 \mathrm{HV}$. The volume fraction of CoWB becomes $\sim 0.4$ after annealing the amorphous alloy for $100 \mathrm{~min}$. However, the microhardness of the composite does not improve but remains constant because the Ni-phase has substantially transformed into the $\mathrm{Ni}_{3} \mathrm{Ta}$ phase, which has much lower microhardness values of $\sim 500 \mathrm{HV}$ [36]. With further annealing, the volume fraction of CoWB remains constant, but the Ni-phase continues to transform into $\mathrm{Ni}_{3} \mathrm{Ta}$. Also, the particle size of $\mathrm{CoWB}$ and $\mathrm{Ni}_{3} \mathrm{Ta}$ increases with annealing time. As a result, the microhardness of the composite becomes even lower.

The composite with the highest microhardness has a very low indentation fracture toughness value. Such a low fracture toughness results from the fact that the composite contains only a small amount of ductile phase, Ni-phase. To improve the indentation fracture toughness of the composite, the formation of $\mathrm{Ni}_{3} \mathrm{Ta}$ must be prevented. For this reason, the refractory metal content of the alloy should be lower. It is also possible to prevent the formation of the $\mathrm{Ni}_{3} \mathrm{Ta}$ by lowering the solubility of the refractory metals in the Ni-phase. When the $\mathrm{Cu}-\mathrm{Ni}, \mathrm{Cu}-\mathrm{W}$, and $\mathrm{Cu}$-Ta binary phase diagrams are examined, it is seen that while copper is completely soluble with nickel, it is completely immiscible with tungsten and tantalum in a solid state [29]. Therefore, if copper is partially substituted for nickel, the tungsten and tantalum content of the Ni-phase forming during annealing is expected to be lower. As a result, there will be no transformation of the Ni-phase into the $\mathrm{Ni}_{3} \mathrm{Ta}$. In addition, increasing the boron content of the alloy might be another way of increasing the fracture toughness. Increasing the boron content will cause the precipitation of a high amount of CoWB, so more refractory metal will take part in the formation of CoWB. As a result, the formation of the $\mathrm{Ni}_{3} \mathrm{Ta}$ will be prevented due to the decrease in the refractory metal content of the Ni-phase. However, while reducing the refractory metal 
content of the alloy, making a copper substitution for nickel, and increasing the boron content of the alloy, care should be taken not to adversely affect the GFA of the alloy.

\section{Conclusions}

In conclusion, CoWB based composites are produced by annealing $\mathrm{Ni}_{33.6} \mathrm{Co}_{23.2} \mathrm{Zr}_{0.5} \mathrm{Ta}_{4}$ $\mathrm{W}_{23.7} \mathrm{~B}_{15}$ bulk metallic glass above the crystallization temperature. Composites having a microhardness of $1400 \mathrm{HV}$ are obtained as a result of precipitation of CoWB. Increasing the annealing time results in a decrease in microhardness due to the increase in the average particle size of $\mathrm{CoWB}$ and transformation of the Ni-phase into $\mathrm{Ni}_{3} \mathrm{Ta}$, whose hardness is much lower than that of the Ni-phase. The $\mathrm{K}_{C}$ of the composite with the highest microhardness is quite low since it contains a small amount of ductile phase, Ni-phase. To improve both the hardness and toughness of the composite, the formation of $\mathrm{Ni}_{3} \mathrm{Ta}$ must be prevented by either decreasing the total refractory metal content or increasing the boron content of the alloy.

\section{Patents}

The patent with the PCT application number PCT/TR2019/050997 has emerged as a result of the studies, some of which are presented in this article.

Author Contributions: Conceptualization, A.H.; methodology, A.H. and Z.O.Y.; validation, A.H., Z.O.Y., H.Ş., P.Ö., B.E. and N.B.; formal analysis, A.H. and H.Ş.; investigation, A.H., Z.O.Y., H.Ş., P.Ö., B.E. and N.B.; resources, H.Ş. and P.Ö.; writing-original draft preparation, A.H.; writing-review and editing, Z.O.Y.; visualization, A.H.; supervision, A.H.; project administration, A.H.; funding acquisition, A.H. All authors have read and agreed to the published version of the manuscript.

Funding: This study was funded by The Scientific and Technological Research Council of Turkey (TUBITAK) (Project No. 214M111).

Data Availability Statement: Data presented in this article are available at request from the corresponding author.

Acknowledgments: The authors are grateful to Mehmet Akkaş and Serhat T1kız for doing the scanning electron microscopy measurements.

Conflicts of Interest: The authors declare that they have no conflict of interest.

\section{References}

1. Zakhariev, Z.; Zlateva, R.; Petrov, K. Microhardness and high-temperature oxidation stability of CoWB. J. Less-Common Met. 1986, 117, 129-133. [CrossRef]

2. Karimi, H.; Hadi, M.; Ebrahimzadeh, I.; Farhang, M.R.; Sadeghi, M. High-temperature oxidation behaviour of WC-FeAl composite fabricated by spark plasma sintering. Ceram. Int. 2018, 44, 17147-17153. [CrossRef]

3. Cao, Z.; Jian, Y.; Huang, Z.; Xu, L.; Fan, J. High-temperature cyclic oxidation behavior and mechanism of $\mathrm{Mo}_{2} \mathrm{FeB}_{2}$-based cermets with various boron contents. Corros. Sci. 2021, 190, 109665. [CrossRef]

4. Sanchez, J.M.; Azcona, I.; Castro, F. Mechanical properties of titanium diboride based cermets. J. Mater. Sci. 2000, 35, 9-14. [CrossRef]

5. Venkateswaran, T.; Basu, B.; Raju, G.B.; Kim, D.Y. Densification and properties of transition metal borides-based cermets via spark plasma sintering. J. Eur. Ceram. Soc. 2006, 26, 2431-2440. [CrossRef]

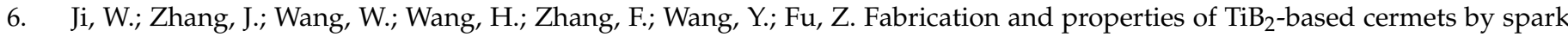
plasma sintering with CoCrFeNiTiAl high-entropy alloy as sintering aid. J. Eur. Ceram. Soc. 2015, 35, 879-886. [CrossRef]

7. Lark, A.; Du, J.; Ravi Chandran, K.S. Material design and processing of a new class of titanium boride cermets with tough metallic phases and mechanical properties. J. Mater. Res. 2018, 33, 4296-4306. [CrossRef]

8. Takagi, K. High tough boride base cermets produced by reaction sintering. Mater. Chem. Phys. 2001, 67, 214-219. [CrossRef]

9. Takagi, K. Development and application of high strength ternary boride base cermets. J. Solid State Chem. 2006, 179, 2809-2818. [CrossRef]

10. Yuan, B.; Zhang, G.J.; Kan, Y.M.; Wang, P.L. Reactive synthesis and mechanical properties of $\mathrm{Mo}_{2} \mathrm{NiB}_{2}$ based hard alloy. Int. J. Refract. Met. Hard Mater. 2010, 28, 291-296. [CrossRef]

11. Lee, D.R.; Lee, W.J. Fabrication of $\mathrm{W}_{2} \mathrm{NiB}_{2}-\mathrm{Ni}$ borides cermets. J. Jpn. Soc. Powder Metall. 2003, 50, 851-855. [CrossRef]

12. Matsuoka, Y.; Fujima, T.; Momozawa, A.; Takagi, K. Mechanical properties of W2NiB2-Ni boride base cermets. J. Jpn. Soc. Powder Metall. 2013, 60, 349-353. [CrossRef] 
13. Yu, H.; Liu, W.; Zheng, Y. Microstructure and mechanical properties of liquid phase sintered $\mathrm{Mo}_{2} \mathrm{FeB}_{2}$ based cermets. Mater. Des. 2011, 32, 3521-3525. [CrossRef]

14. Takagi, K.; Koike, W.; Momozawa, A.; Fujima, T. Effects of Cr on the properties of Mo2NiB2 ternary boride. Solid State Sci. 2012, 14, 1643-1647. [CrossRef]

15. Zhang, L.; Huang, Z.; Shen, Y.; Guo, L. Bulk $\mathrm{Mo}_{2} \mathrm{FeB}_{2}$ based cermets fabricated by mechanical ball milling and reaction boronizing sintering. Powder Metall. Met. Ceram. 2017, 55, 665-675. [CrossRef]

16. Wu, H.; Zheng, Y.; Zhang, J.; Zhang, G.; Ke, Z.; Xu, X.; Lu, X.; Zhou, W. Preparation of Mo2FeB2-based cermets with a core/rim structure by multistep sintering approach. Ceram. Int. 2019, 45, 22371-22375. [CrossRef]

17. Ivanov, M.B.; Vershinina, T.N.; Ivanisenko, V.V. The effect of composition and microstructure on hardness and toughness of Mo2FeB2 based cermets. Mater. Sci. Eng. A 2019, 763, 138117. [CrossRef]

18. $\mathrm{Wu}, \mathrm{H} . ; \mathrm{Zheng}, \mathrm{Y} . ; \mathrm{Zhang}$, J.; Zhang, G.; Ke, Z.; Xu, X.; Lu, X. Influence of $\mathrm{Cr}$ and $\mathrm{W}$ addition on microstructure and mechanical properties of multi-step sintered $\mathrm{Mo}_{2} \mathrm{FeB}_{2}$-based cermets. Ceram. Int. 2020, 46, 10963-10970. [CrossRef]

19. Li, J.; Li, J.; Li, C.; Liu, Y. Reactive synthesis of FeWB powders and preparation of bulk materials. Int. J. Refract. Met. Hard Mater. 2014, 46, 80-83. [CrossRef]

20. Hongwei, Y.; Jun, L.; Cheng, L.; Ying, L. Microstructure evolution and phase transformation of FeWB based cermets during the vacuum sintering. Rare Metal Mat. Eng. 2018, 47, 463-468. [CrossRef]

21. Zhang, T.; Yin, H.; Zhang, C.; Zhang, R.; Yang, Z.; Elder, S.; Jiang, X.; Deng, Z.; Yang, G.; Zheng, Q.; et al. Synthesis and microstructure evolution of WCoB based cermets during spark plasma sintering. Ceram. Int. 2019, 45, 17536-17544. [CrossRef]

22. Zhang, T.; Yin, H.; Zhang, C.; Qu, X. Microstructure and mechanical properties of Cr doped WCoB based cermets by spark plasma sintering and first principle calculation. Prog. Nat. Sci. 2020, 30, 417-423. [CrossRef]

23. Yang, G.; Yin, H.; Deng, Z.; Zhang, C.; Zhang, R.; Qu, X. Effect of chemical composition on the microstructure and mechanical properties of MoCoB based cermets. Ceram. Int. 2020, 46, 18046-18055. [CrossRef]

24. Fornell, J.; Gonzales, S.; Rossinyol, E.; Surinach, E.; Baro, M.D.; Louzguine-Luzgin, D.V.; Perepezko, J.H.; Sort, J.; Inoue, A Enhanced mechanical properties due to structural changes induced by devitrification in Fe-Co-B-Si-Nb bulk metallic glass. Acta Mater. 2010, 58, 6256-6266. [CrossRef]

25. Han, J.J.; Wang, C.P.; Kou, S.Z.; Liu, X.J. Thermal stability, crystallization behavior, Vickers hardness and magnetic properties of $\mathrm{Fe}-\mathrm{Co}-\mathrm{Ni}-\mathrm{Cr}-\mathrm{Mo}-\mathrm{C}-\mathrm{B}-\mathrm{Y}$ bulk metallic glasses. Trans. Nonferrous Met. Soc. China 2013, 23, 148-155. [CrossRef]

26. Hitit, A.; Geçgin, M.; Öztürk, P. Effect of annealing on microstructure and microhardness of Co-Fe-Ni-Ta-B-Si bulk metallic glass. J. Mater. Sci. Technol. 2015, 31, 148-152. [CrossRef]

27. Hitit, A.; Yazici, Z.O.; Öztürk, P.; Şahin, H.; Aşgın, A.M.; Hitit, B. A Ni-CoWB composite developed by devitrification of Ni-Co-W-B bulk metallic glass. Mater. Sci. Eng. A 2021, 803, 140479. [CrossRef]

28. Hitit, A.; Yazici, Z.O.; Öztürk, P.; Eryeşil, B.; Barut, N.; Şahin, H. The effects of tantalum addition on the glass forming ability, thermal stability, and mechanical properties of Ni-Co-W-B bulk metallic glasses. J. Non-Cryst. Solids 2021, 572, 121089. [CrossRef]

29. Massalski, T. Binary Alloy Phase Diagrams; ASM International: Materials Park, OH, USA, 1992; Volume 3.

30. Lonsdale, K. International Tables for X-ray Crystallography; Dordrecht u.a.: Kluwer, UK, 1968.

31. Evans, A.G.; Wilshaw, T.R. Quasi-static solid particle damage in brittle solids-I. Observations, analysis and implications. Acta Metall. 1976, 24, 939-956. [CrossRef]

32. Evans, A.G.; Charles, E.A. Fracture toughness determinations by indentation. J. Am. Ceram. Soc. 1976, 59, 371-372. [CrossRef]

33. Aning, A.O.; Wang, Z.; Courtney, T.H. Tungsten solution kinetics and amorphization of nickel in mechanically alloyed Ni-W alloys. Acta Metall. 1993, 41, 165-174. [CrossRef]

34. Yamasaki, T.; Schloßmacher, P.; Ehrlich, K.; Ogino, Y. Formation of amorphous electrodeposited Ni-W alloys and their nanocrystallization. Nanostruct. Mater. 1998, 10, 375-388. [CrossRef]

35. Rupert, T.J.; Schuh, C.A. Sliding wear of nanocrystalline Ni-W: Structural evolution and the apparent breakdown of Archard scaling. Acta Metall. 2010, 58, 4137-4148. [CrossRef]

36. Yıldı, K. Investigation of Structural Properties and Martensitic Phase Transformations in Heat-treated Ni-25.5 at. \%Ta High Temperature Shape Memory Alloys. ADYU J. Sci. 2020, 10, 391-402. [CrossRef] 